The University of Maine

\title{
DigitalCommons@UMaine
}

Earth Science Faculty Scholarship

Earth Sciences

5-1-1997

\section{Pliocene Paleoenvironment and Antarctic Ice Sheet Behavior: Evidence from Wright Valley}

Brenda L. Hall

University of Maine-Main, brendah@maine.edu

George H. Denton

University of Maine - Main, gdenton@maine.edu

Daniel R. Lux

University of Maine - Main, dlux@maine.edu

Christian Schlüchter

Follow this and additional works at: https://digitalcommons.library.umaine.edu/ers_facpub

Part of the Earth Sciences Commons

\section{Repository Citation}

Hall, Brenda L.; Denton, George H.; Lux, Daniel R.; and Schlüchter, Christian, "Pliocene Paleoenvironment and Antarctic Ice Sheet Behavior: Evidence from Wright Valley" (1997). Earth Science Faculty Scholarship. 67.

https://digitalcommons.library.umaine.edu/ers_facpub/67 


\title{
A R T I C L E S
}

\section{Pliocene Paleoenvironment and Antarctic Ice Sheet Behavior: Evidence from Wright Valley ${ }^{1}$}

\author{
Brenda L. Hall, George H. Denton, ${ }^{2}$ Daniel R. Lux, and Christian Schlüchter ${ }^{3}$ \\ Department of Geological Sciences, University of Maine, Orono, Maine 04469-5711
}

\begin{abstract}
Investigations in Wright Valley, adjacent to the Transantarctic Mountains in East Antarctica, shed light on the question of whether high-latitude Pliocene climate was warm enough to cause widespread deglaciation of the East Antarctic craton with a concurrent Magellanic moorland-like environment. If Pliocene-age diatoms, presently in glaciogenic deposits high in the Transantarctic Mountains, had come from seaways on the East Antarctic craton, an expanding Late Pliocene ice sheet must have first eroded them from marine sediments and then deposited the diatoms at their present high-altitude locations. This hypothetical expanding glacier would have had to have come through Wright Valley. Glacial drift sediments from the central Wright Valley were mapped, sampled, analyzed, and ${ }^{40} \mathrm{Ar} /{ }^{39} \mathrm{Ar}$ wholerock dated. Our evidence indicates that an East Antarctic outlet glacier has not expanded through Wright Valley, and hence cannot have overridden the Dry Valleys sector of the Transantarctic Mountains, any time in the past 3.8 myr. Rather, there was only moderate Pliocene expansion of local cold-based alpine glaciers and continuous cold-desert conditions in Wright Valley. Persistence of a cold-desert paleoenvironment implies that the sector of the East Antarctic Ice Sheet adjacent to Wright Valley has remained relatively stable without melting ablation zones since at least 3.8 $\mathrm{Ma}$, in Early Pliocene time. A further implication is that Antarctic Ice Sheet behavior in the Pliocene was much like that in the Quaternary, when the ice sheet consisted of a stable, terrestrial core in East Antarctica and a dynamic, marine-based appendage in West Antarctica.
\end{abstract}

\section{Introduction: The Problem}

Numerous paleoclimate records indicate that Pliocene climate was warmer than at present in many sectors of the planet between 3.0 and $4.8 \mathrm{Ma}$ (Kennett and Hodell 1993; Cronin and Dowsett 1993). An unresolved issue is whether the climate of East Antarctica was sufficiently warm during this time interval to feature inland seas with surface temperatures of $2-5^{\circ} \mathrm{C}$ (Harwood 1986), temperate ice caps, and Nothofagus (southern beech) forests in place of the present-day continent-wide polar ice sheet (Denton et al. 1993; Webb and Harwood 1991; Webb et al. 1984). This problem bears not only on the evolution of a polar East Antarctic Ice Sheet, but also on its sensitivity to greenhouse warming (Barrett 1991).

The hypothesis of massive deglaciation is based on the assumption that Pliocene diatoms, now

\footnotetext{
${ }^{1}$ Manuscript received September 5, 1996; accepted December 12, 1996.

${ }^{2}$ Also: Institute for Quaternary Studies, University of Maine, Orono, Maine 04469.

${ }^{3}$ Geologisches Institut, Universität Bern, CH-3012 Bern, Switzerland.
}

present within Sirius Group glaciogenic deposits high in the Transantarctic Mountains, once lived in interior marine basins that would have formed if the East Antarctic Ice Sheet collapsed (figure 1). The ice sheet is thought to have eroded the diatoms and emplaced them in Sirius sediments when it readvanced over the basins and then across the Transantarctic Mountains in Late Pliocene or Early Pleistocene time (Webb et al. 1984; Webb and Harwood 1991; Barrett et al. 1992). In addition, Nothofagus and Dacrydium fossil remains occur essentially in situ in Sirius outcrops beside Beardmore Glacier (Askin and Markgraf 1986; Ashworth et al. 1996). Given the assumptions about the age of the Sirius deposits, they are thought to be representative of Late Pliocene vegetation in the Transantarctic Mountains (Webb and Harwood 1993). Pliocene ice-sheet collapse and development of krummholz Nothofagus in Antarctica both require atmospheric temperatures $20-25^{\circ} \mathrm{C}$ greater than now (Barrett 1991; Huybrechts 1993; Sakai et al. 1981).

The hypothesis of Pliocene ice-sheet collapse carries specific predictions. The combination of

[The Journal of Geology, 1997, vol. 105, p. 285-294] @ 1997 by the University of Chicago. All rights reserved. 0022-1376/97/10503-0007\$01.00 


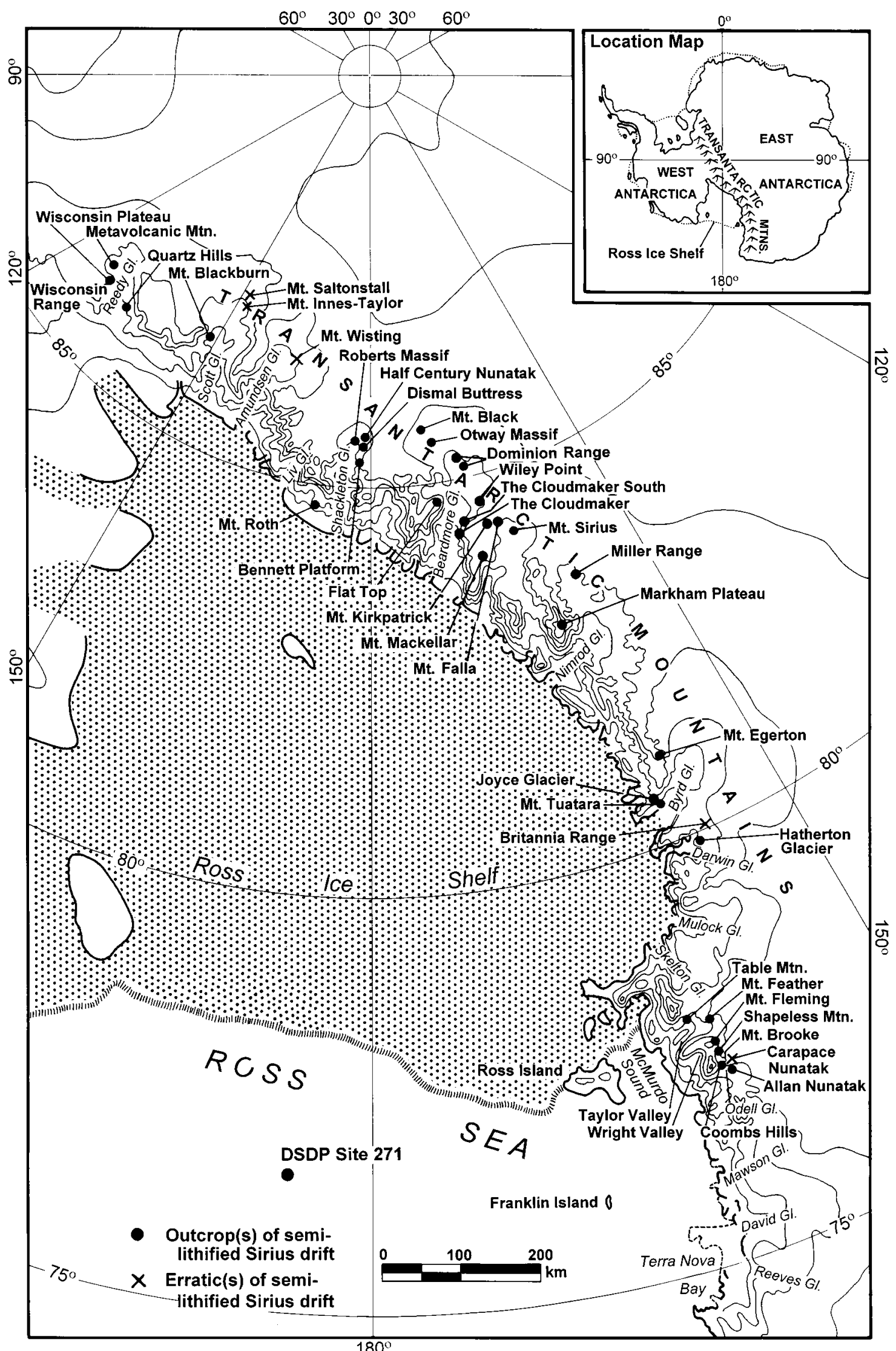

$180^{\circ}$ 
Nothofagus and Dacrydium remains suggests that an environment similar to the modern Magellanic moorland of southern Chile existed in the Transantarctic Mountains near Beardmore Glacier during deposition of the Sirius Group ("Tundra Magallánica" of Pisano 1977, 1983; Mercer 1986; Ashworth et al. 1996). Presumably, these conditions also applied to the Dry Valleys, as Webb and Harwood (1993) postulated that Wright Valley supported local Nothofagus rainforests with ferns (Hall 1975) in Late Miocene or Pliocene time. Abundant rainfall (between 800 and $>6000 \mathrm{~mm} /$ yr), pervasive cloudiness, and frequent storms characterize the Magellanic moorland environment in southern South America (Pisano 1977, 1983). Nothofagus and Dacrydium (Lepidothamnus in South America) both require reliable and plentiful rainfall, generally at least $1500 \mathrm{~mm} / \mathrm{yr}$ (Howard 1981; Pisano 1983). Mean temperature for February (the warmest month) at treeline in Tierra del Fuego (600 $\mathrm{m}$ elevation) is about $4^{\circ} \mathrm{C}$ (Puigdefabregas et al. 1988). In this environment, the $0^{\circ} \mathrm{C}$ isotherm in the atmosphere intersects glaciers well above sea level (Robin 1988), resulting in temperate ice tongues with surface melting zones in summer. Here, sediment-laden meltwater forms kame terraces and extensive plains of coarse outwash. Slopes adjacent to these temperate alpine glaciers commonly display thick alluvial fans and colluvium. Thus, the postulated existence of a Magellanic moorland environment in Antarctica during Pliocene time carries the implication of elevated temperatures, abundant rainfall, active slopes, and temperate-glacier landforms.

The Wright Valley $\left(77^{\circ} 30^{\prime} \mathrm{S}\right)$ terrestrial record is ideal for testing hypotheses of Pliocene paleoclimate and ice-sheet extent because the valley is adjacent to the East Antarctic Ice Sheet, contains widespread Pliocene-age deposits, and has a lowelevation floor. Wright Valley trends through the Dry Valleys sector of the Transantarctic Mountains from the polar plateau to the Ross Sea (figure 2). Wright Upper Glacier drains the peripheral Taylor Dome (2450 m elevation) of the East Antarctic Ice Sheet and terminates at the valley head $(1000 \mathrm{~m}$ elevation). Wright Lower Glacier, a lobe of Wilson Piedmont Glacier, blocks the eastern valley mouth. Five small, cold-based alpine glaciers (Goodspeed, Hart, Meserve, Bartley, and Conrow) flow down the south valley wall and terminate at 200 to $545 \mathrm{~m}$ elevation.

Today, Wright Valley is a cold desert with a mean annual temperature on the valley floor of $-20^{\circ} \mathrm{C}$ (range of $-57^{\circ} \mathrm{C}$ to $+10^{\circ} \mathrm{C}$ ) and only $0.7-8.2$ $\mathrm{mm}$ of precipitation (water equivalent) (Thompson et al. 1971). Accumulation of wind-blown snow controls the distribution of glaciers, which are polar (Meserve Glacier has a basal temperature of $-18^{\circ} \mathrm{C}$; Bull and Carnein 1968). Most ablation of glacier ice $(>90 \%)$ occurs by sublimation, with the remainder $(<10 \%)$ by melting (Chinn 1980). These polar glaciers now deposit coarse-grained and unstratified moraines. Ephemeral meltwater streams form small sand-and-fine gravel fans and deltas. Non-glacial geomorphic features include aeolian sand sheets, ripples, and dunes, along with desert pavement, contraction cracks, and patchy, thin colluvium and gelifluction on valley slopes. Conspicuously lacking are deposits common in temperate glaciated landscapes, including thick alluvial fans, kame terraces, and outwash plains graded to moraines and ice-contact heads.

\section{Glacial Deposits of Wright Valley}

Unconsolidated glacial drifts are exposed widely in central Wright Valley. In addition, in situ airfall ash $(3.9 \mathrm{Ma})$ and relict colluvium $(>3.9 \mathrm{Ma})$ rest on the valley slopes (Hall et al. 1993). We separated these and other surficial deposits into map units based on areal extent, geometric relationships, morphology, soil development, and surface-boulder weathering (figure 3). The physical characteristics of the map units come from detailed examination of 292 handdug excavations, along with analyses of 30 sediment and 30 clast samples for grain size, lithology, sedimentology, shape, and surface textures.

The stratigraphically lowest drift is Peleus till, which is silty and contains numerous striated clasts. Peleus till occurs discontinuously from 180 $\mathrm{m}$ elevation on the valley floor to $1150 \mathrm{~m}$ on the south valley wall. It is preserved only below about $300 \mathrm{~m}$ elevation on the steep north valley wall. Peleus till lacks associated lateral or terminal moraines. The areal distribution of enclosed sandstone erratics, along with underlying striated bedrock and crescentic gouges, indicate that Peleus till was deposited by a wet-based East Antarctic outlet gla-

Figure 1. Numerous Sirius Group outcrops occur at high elevations in the Transantarctic Mountains along the western coast of the Ross Sea. Two of the sites (Mt. Fleming and Mt. Feather) are close to our field area. This map also shows DSDP Site 271 at which Alonso et al. (1992) have found evidence for Pliocene-age advances of grounded ice over the Ross Sea continental shelf. 


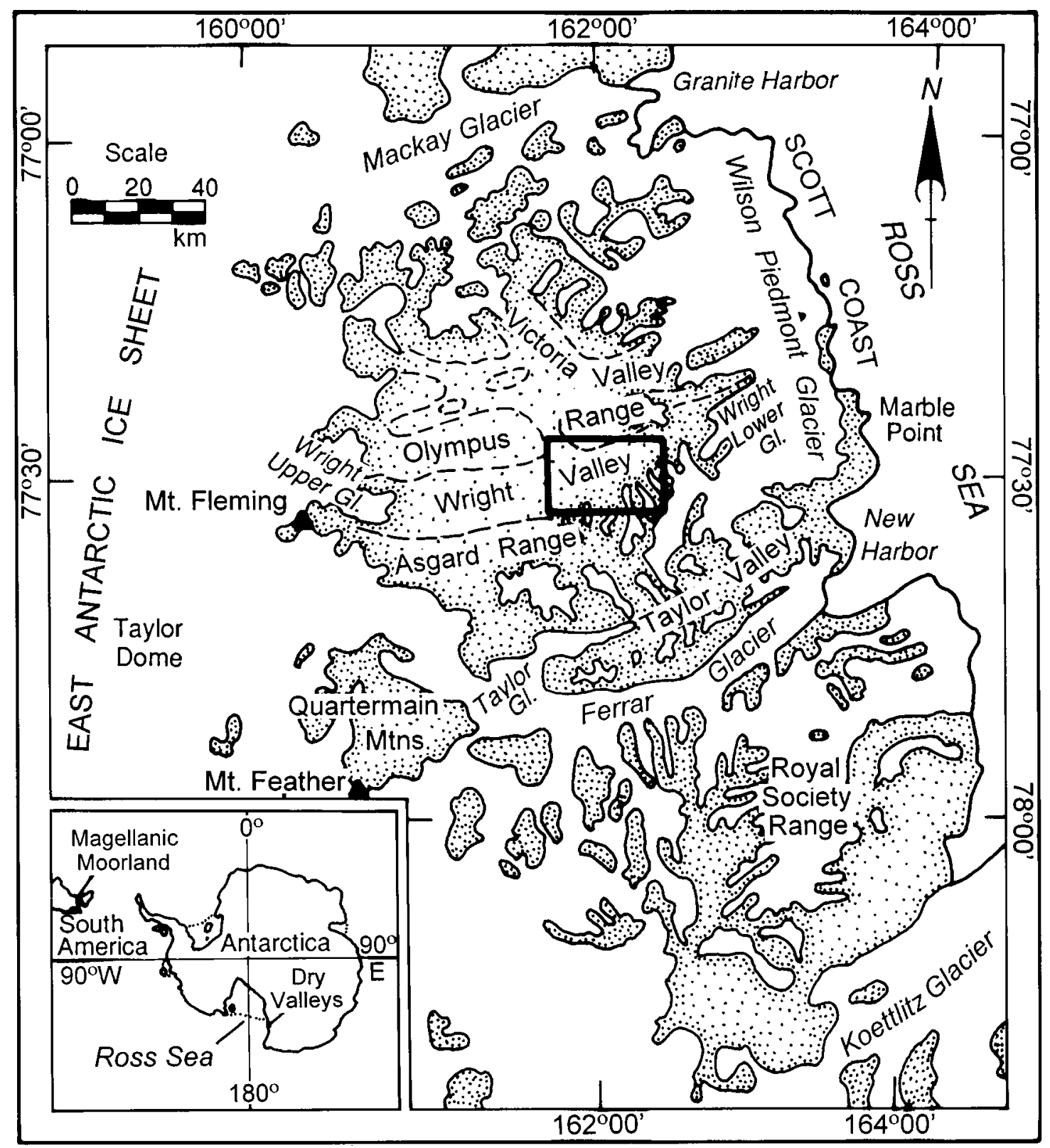

Figure 2. Index map of the Dry Valleys showing the principal localities mentioned in the text. The box shows the location of figure 3 .

cier that flowed seaward through Wright Valley (Hall et al. 1993; Prentice et al. 1993). The geometric relationship between Peleus till and contemporaneous alpine drift at Bartley Glacier indicates that alpine glaciers on the south valley wall expanded to merge with the eastward-flowing Peleus ice tongue.

Stratigraphically above Peleus till is a complex of loose, sandy drifts (Alpine I-IV) that lacks striated clasts (except where they incorporate blocks of Peleus till), contains numerous ventifacts, and forms moraines alongside the alpine glaciers on the south valley wall. Peleus till occurs beneath rightlateral Alpine IV drift and alongside left-lateral, rock-glacier-like lobes composed of old alpine drift at Bartley Glacier. Peleus till also extends to the edge of, but not over, the outermost alpine drifts beside Meserve and Hart Glaciers. These relationships show that Peleus till is older than all recognized alpine drifts in Wright Valley.

The alpine drifts all lie within a kilometer of present-day glacier margins. We divide these alpine drifts into two distinct groups on the basis of soil development, surface boulder weathering, and mor- 


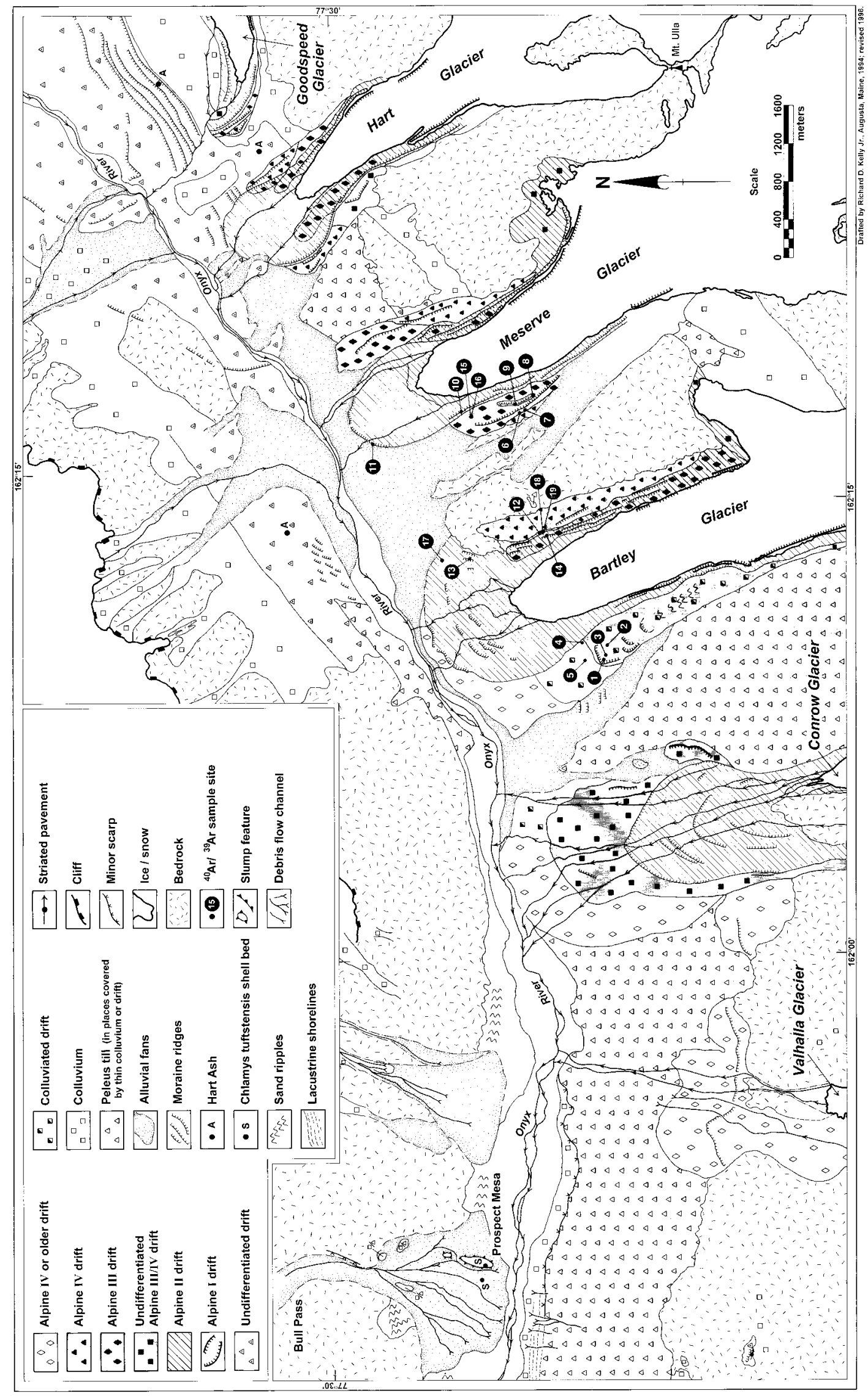

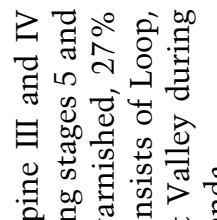

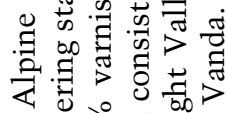

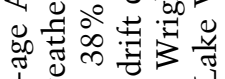
䒕요웜

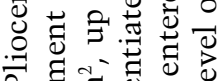

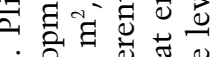

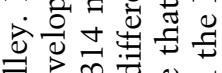

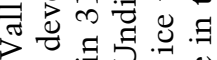

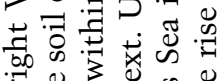
క.

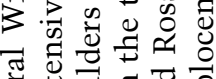

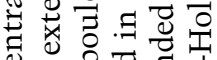
可焉焉

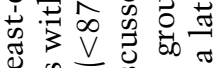
急

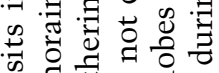

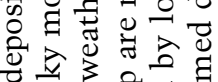

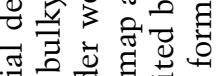

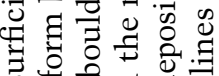
के पे क्य 希 定

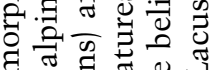

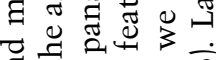
च्च

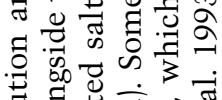

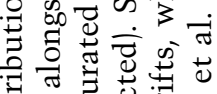

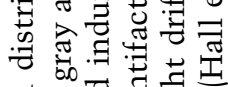

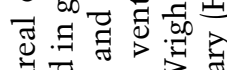

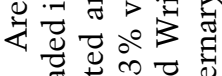

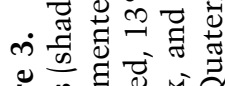

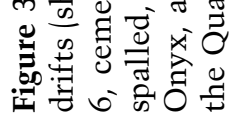


Table 1. ${ }^{40} \mathrm{Ar} /{ }^{39} \mathrm{Ar}$ Ages for Reworked Basalt Clasts within Wright Valley Alpine Drifts with Samples Keyed to Figure 3

\begin{tabular}{|c|c|c|c|}
\hline $\begin{array}{l}\text { Sample } \\
\text { (Fig. 1) }\end{array}$ & $\begin{array}{l}\text { Age } \\
(\mathrm{Ma})\end{array}$ & ${ }^{40} \mathrm{Ar} /{ }^{39} \mathrm{Ar}$ & Significance \\
\hline \multicolumn{4}{|c|}{ Left-lateral undifferent. drift, Bartley Glacier; 1 population, mean age $3.8 \pm 0.2 \mathrm{Ma}$ : } \\
\hline 1 & $3.6 \pm .2$ & $299.5 \pm 6.8$ & Maximum age for Alpine III/IV drift \\
\hline 2 & $3.7 \pm .3$ & $301.6 \pm 21.6$ & Minimum age for underlying, basalt-free \\
\hline 3 & $3.8 \pm .2$ & $\ldots$ & Peleus till \\
\hline 4 & $3.8 \pm .2$ & $298.7 \pm 15.8$ & \\
\hline 5 & $3.9 \pm .3$ & $291.6 \pm 10.6$ & \\
\hline \multicolumn{4}{|c|}{ Left-lateral Alpine III drift, Meserve Glacier; 1 population, mean age $3.4 \pm 0.1 \mathrm{Ma}$ : } \\
\hline 15 & $3.3 \pm .4$ & $302.9 \pm 9.1$ & Maximum age for Alpine III drift \\
\hline 16 & $3.3 \pm .2$ & $298.9 \pm 4.7$ & Minimum age for underlying, basalt-free \\
\hline 6 & $3.4 \pm .1$ & $301.2 \pm 6.2$ & Alpine IV drift \\
\hline 7 & $3.5 \pm .1$ & $297.7 \pm 6.2$ & \\
\hline \multicolumn{4}{|c|}{ Left-lateral Alpine II drift, Meserve Glacier; 1 population, mean age $3.6 \pm 0.3 \mathrm{Ma}$ : } \\
\hline 8 & $3.2 \pm .1$ & $297.5 \pm 15.5$ & Maximum age for Alpine II drift \\
\hline 9 & $3.6 \pm .2$ & $293.7 \pm 13.1$ & \\
\hline 10 & $3.7 \pm .1$ & $295.8 \pm 11.4$ & Minimum age for underlying, basalt-free \\
\hline 11 & $3.7 \pm .3$ & $297.8 \pm 13.6$ & Alpine IV drift \\
\hline \multicolumn{4}{|c|}{ Right-lateral Alpine II drift, Bartley Glacier; 2 populations, mean ages $3.7 \pm 0.1,2.9 \pm 0.1 \mathrm{Ma}$ : } \\
\hline $18^{\circ}$ & $2.8 \pm .2$ & $307.0 \pm 9.8$ & Maximum age for Alpine II drift \\
\hline 17 & $2.9 \pm .3$ & $306.4 \pm 33.1$ & Minimum age for underlying, basalt-free \\
\hline 19 & $3.0 \pm .3$ & $303.9 \pm 11.7$ & Alpine IV drift \\
\hline 12 & $3.6 \pm .1$ & $292.0 \pm 3.7$ & \\
\hline 13 & $3.7 \pm .2$ & $302.4 \pm 8.9$ & \\
\hline 14 & $3.7 \pm .1$ & $302.1 \pm 9.6$ & \\
\hline \multicolumn{4}{|c|}{ Basalt cones in the Meserve Glacier accumulation basin (not on map): } \\
\hline$\ldots$ & $3.3 \pm .4$ & $307.2 \pm 30.5$ & Age of cone at south end of basin \\
\hline$\ldots$ & $3.4 \pm .3$ & $311.0 \pm 18.5$ & Age of cone on west wall of basin \\
\hline
\end{tabular}

Note. All ages are isotope correlation ages with the exception of sample 3. We use a plateau age for this sample because its isotope correlation line was not well defined. The ratio of ${ }^{40} \mathrm{Ar} /{ }^{39} \mathrm{Ar}$ is the intercept value of the isotope correlation diagram. Because this ratio in our samples is close to the modern atmospheric ratio (295.5), we have confidence that the trapped component of argon in our samples is of an atmospheric origin and has not been contaminated by argon from another source, such as a xenocryst. Additional criteria and methods for evaluating age estimates and populations are discussed in Hall et al. (1993).

phology. The younger group (Alpine I and II drifts) forms small moraines (1-4 m high) that exhibit relatively little weathering and soil development and thus are probably Quaternary in age (Hall et al. 1993). The older group (Alpine III and IV drifts) is comprised of bulky moraines (10 m high) with extensive soil development and surface-boulder weathering. We infer that the strongly weathered Alpine III and IV drifts are pre-Quaternary in age based on comparison with soil data collected from isotopically dated pre-Quaternary drifts in nearby Taylor and Arena Valleys (Bockheim 1977; Marchant et al. 1993; Wilch et al. 1993).

\section{${ }^{40} \mathrm{Ar} /{ }^{39} \mathrm{Ar}$ Chronology}

Numerous basalt clasts contained within some alpine drifts were reworked from volcanic cones now adjacent to and partially under upper Meserve Glacier and inferred to be beneath upper Bartley Glacier (Hall et al. 1993). We carried out whole-rock ${ }^{40} \mathrm{Ar} /{ }^{39} \mathrm{Ar}$ age determinations on 21 basalt clasts to produce the following drift chronology (table 1).
Alpine III Drift Postdates 3.4 Ma. This age estimate comes from reworked basalt clasts (sites 6, 7, 15,16 in table 1 and figure 3 ) incorporated within the left-lateral Alpine III moraine of Meserve Glacier.

Alpine IV Drift Antedates 3.7 Ma. At Bartley Glacier, right-lateral Alpine II drift with numerous basalt clasts (up to $40 \%$ of the total clasts) overlies basalt-free Alpine IV drift. The basalt clasts in Alpine II drift are up to $3.7 \mathrm{Ma}$ old (sites 12, 13, 14) and were reworked from a volcanic cone now beneath the catchment area of Bartley Glacier. If this cone had been present before the Alpine IV advance, then Alpine IV drift would surely contain reworked basalt clasts. Therefore, the basalt clasts within Alpine II drift afford a minimum age of 3.7 Ma for Alpine IV drift. At Meserve Glacier, leftlateral Alpine III drift with reworked basalt clasts dated to $3.4 \mathrm{Ma}$ (sites 6, 7, 15, 16) overlies Alpine IV drift, which is devoid of basalt clasts. Again, we infer that Alpine IV drift at Meserve Glacier antedates 3.4 Ma.

Peleus Till is Older Than 3.8 Ma. This age esti- 
mate comes from two sources. Peleus till is overlain by Alpine IV drift, which is older than 3.7 Ma. Also, Peleus till must be older than basalt erratics dated to $3.8 \mathrm{Ma}$ in overlying undifferentiated, reworked alpine drift alongside the western margin of Bartley Glacier (sites 1, 2, 3, 4, 5). This interpretation comes from the fact that all but the oldest (Alpine IV) Bartley Glacier drifts are rich in basalt clasts glacially transported down the southern valley wall. Based on the situation today, where Bartley Glacier reaches the valley floor yet the East Antarctic outlet glacier is still nearly $40 \mathrm{~km}$ to the west, we believe that the Pliocene-age Bartley Glacier had already reached the valley floor before it merged with the advancing Peleus axial glacier. If they were present, basalt clasts would have been transported to the floor of Wright Valley by Bartley Glacier and subsequently incorporated into Peleus till. Therefore, the absence of reworked basalt clasts suggests that Peleus till was deposited prior to the eruption of basalt about $3.8 \mathrm{Ma}$ in the catchment area of Bartley Glacier.

\section{Prospect Mesa}

Peleus till is well-exposed in section at Prospect Mesa (figure 3), a 15-m-high butte (about $300 \mathrm{~m}$ long and $120 \mathrm{~m}$ wide) that trends N-S and rests on what was once a submarine fan. The mesa consists of Peleus till capped by colluvium. It is underlain by Prospect Mesa gravel, which contains marine shells (Chlamys tuftstensis; Turner 1967) and microfossils (Prentice et al. 1993). Prospect Mesa gravel composes the surface of the former submarine fan and can be traced as a surficial deposit along the undisturbed fan surface west of Prospect Mesa. Prentice et al. (1993) suggested that the Peleus Glacier advanced over the fan and deposited Peleus till. Subsequent erosion was thought to have removed all but the remnants of Peleus till now exposed in the mesa. Thus Prentice et al. (1993) used dates derived from the shells $(5.5 \mathrm{Ma})$ and microfossils (Pliocene) within the Prospect Mesa gravel to afford a maximum age for Peleus till, which is widespread elsewhere in central Wright Valley.

We now present evidence which we believe indicates that Peleus till and overlying colluvium within Prospect Mesa are not in situ, but instead have slumped down the hillside and come to rest on top of the fan. First, Peleus till exposed at Prospect Mesa is highly fractured and contains "peanut" structures, indicative of slumped sediment. In addition, the shell bed in Prospect Mesa gravel underlying Peleus till has been overturned and folded by downslope movement. Moreover, numerous shells in growth position occur in Prospect Mesa gravel on the surface of the fan just west of Prospect Mesa itself at locations not now covered by Peleus till. These undisturbed shells are at the same stratigraphic level as the shell bed folded beneath Prospect Mesa. It is highly improbable that these fragile shells could have survived overriding by a wetbased Peleus outlet glacier and the subsequent erosion of an overlying layer of Peleus till and colluvium similar to that in the mesa. Finally, the fan surface has been rotated beneath Prospect Mesa. Alongside the mesa, the fan surface is well-preserved and slopes toward the valley floor. Beneath the mesa near its downhill (south) end, the fan surface has a concave profile. We believe that slumping of the Peleus till block onto the fan caused a failure within a silt bed beneath the Prospect Mesa gravels, leading to rotation of the overlying sediments (Prospect Mesa gravels, Peleus till, and colluvium). Therefore, we believe that Prospect Mesa formed when Peleus till (with a colluvial cap) slumped downslope onto the Prospect Mesa gravels, which make up the fan surface. This slumping probably occurred during the fjord episode, when sediment on the valley slopes would have been water-saturated and hence unstable. Thus, dates from shells and microfossils in Prospect Mesa gravels do not afford a maximum age for Peleus till in Wright Valley. Instead, they represent a minimum age for Peleus till if it is assumed that delicate Chlamys tuftstensis shells in growth position on the fan could not have survived overriding by Peleus ice.

\section{Wright Valley Fjord}

Marine microfossils and Chlamys tuftstensis shells in Prospect Mesa gravel at $165 \mathrm{~m}$ elevation at and near Prospect Mesa indicate that a fjord, here about $100 \mathrm{~m}$ deep, occupied Wright Valley at some time during the Early-to-mid Pliocene (figures 2, 3; Webb 1972; Prentice et al. 1993). Pliocene Alpine III and IV lateral moraines at Bartley, Meserve, and Hart Glaciers all end abruptly in steep ramps at approximately 300 m elevation. Goodspeed Glacier, which terminates at a higher elevation $(545 \mathrm{~m})$, has nearcomplete terminal Alpine III and IV moraines. Conrow Glacier, which differs from the other local alpine glaciers in that its advances are much more extensive, displays remnant moraine pieces and an undulating drift sheet of Alpine III or IV age in the terminal area. Elsewhere, we have suggested that the reason for the absence of terminal moraines at most of the glaciers is that the thin, slow-moving alpine glaciers terminated and calved at the Pliocene fjord margin during the Alpine III and IV maxima (Hall et al. 1993). Since the Pliocene fjord epi- 
sode, surface uplift of Wright Valley has raised the lower ends of the moraines from sea level (ignoring eustatic changes) to about $300 \mathrm{~m}$ elevation. This estimate of post-fjord surface uplift is consistent with a value of $<300 \mathrm{~m}$ of uplift since $2.57 \mathrm{Ma}$ obtained by Wilch et al. (1993) for nearby Taylor Valley. These constraints on the former elevation of Wright Valley sediments and landforms afford a background for reconstructing paleoenvironmental conditions.

\section{Pliocene Paleoenvironments}

The Pliocene landform assemblage in Wright Valley is similar to that forming in the present colddesert environment. Because Alpine III and IV drifts are identical in sedimentology, composition, and textural features to drifts being deposited by present-day polar glaciers, we infer that Pliocene alpine glaciers also were polar. Continuous cold-based conditions are consistent with the fact that alpine glaciers on the south wall have not carved out basal troughs. The presence of in situ airfall ash on the valley walls and the lack of significant development of colluvium since at least 3.9 Ma both indicate slope stability consistent with a cold, hyperarid environment extending back at least to Early Pliocene time. Such slope stability is not characteristic of temperate glaciated areas, where thick colluvial deposits, rockfalls, and large alluvial fans are common. In addition, the Pliocene landform assemblage lacks temperate glacier deposits, such as kame terraces and coarse-grained outwash plains graded to moraines and ice-contact heads. Furthermore, temperate glaciomarine lithofacies (moraine banks, diamictons formed from subglacial and melt-out till, gravity flows, deltas and subaqueous fans, ice-rafted detritus, and laminated muds) are absent. Isolated patches of glacial or glaciomarine(?) silt occur locally, but are older than the Prospect Mesa gravels. Because the Wright Valley alpine glaciers terminated in a fjord, glaciomarine landforms and sediments should have been present if the glaciers were temperate. Consequently, we conclude that alpine glaciers in Wright Valley were cold-based and existed in a hyperarid, polar climate when Alpine IV drift was deposited at sea level before 3.7 Ma. This paleoenvironmental reconstruction is compatible with the lower end of the sea water temperature ranges postulated for the Wright Valley fjord $\left(-2\right.$ to $+10^{\circ} \mathrm{C}$ from benthic foraminifera; Webb 1972, 1974; 0 to $<3^{\circ} \mathrm{C}$ based on the diatom assemblage and lack of coccolithophores; Burckle and Pokras 1991, Prentice et al. 1993). The lack of temperate-ice deposits and landforms superimposed on the Pliocene drifts indi- cates that similar cold-desert conditions have persisted since at least 3.7 Ma.

We note that neither the presence of a wet-based Peleus axial glacier nor the existence of a fjord are incompatible with our evidence for cold, polar conditions. Wet-basal conditions do not occur solely beneath temperate glaciers. Thick and/or fastmoving polar ice may have at least local wet-based conditions. Outlet glaciers in the Transantarctic Mountains, such as Taylor Glacier, are at least partially wet-based today (Robinson 1984). Quaternary-aged till adjacent to some of these outlet glaciers contains abundant striated stones in a rockflour matrix. Heavily striated and polished surfaces created by late Wisconsin-aged ice occur adjacent to Mackay Glacier today. There is no suggestion that Mackay Glacier was temperate during late Wisconsin time, yet it was most surely wet-based. Finally, the presence of a fjord in Wright Valley during Early Pliocene time does not preclude cold, polar conditions. Fjords exist in the Antarctic today (such as the fjord in Ferrar Valley, less than $100 \mathrm{~km}$ south of Wright Valley).

Our data for limited alpine glacier expansion of less than a kilometer and hyperarid polar deserts in Wright Valley since Early Pliocene time bear on the problem of Pliocene ice-sheet configuration and paleoclimate in East Antarctica. An age in excess of 3.8 Ma for Peleus till is inconsistent with ice-sheet expansion over the Transantarctic Mountains after 3.0 Ma (Barrett et al. 1992) thought necessary to emplace diatoms in Sirius deposits (for example, at $2250 \mathrm{~m}$ elevation on Mt. Fleming at the head of Wright Valley and $2600 \mathrm{~m}$ elevation on Mt. Feather in the western Dry Valleys, figure 2). In addition, we suggest that cold-based alpine glaciers terminated at sea level $<35 \mathrm{~km}$ from the East Antarctic Ice Sheet in Early Pliocene time. The polar climate at sea level associated with these alpine glaciers is inconsistent not only with the postulated local Nothofagus forests, but also with the Magellanic moorland environment suggested for the Beardmore Glacier area. Rainfall in excess of $1500 \mathrm{~mm} /$ yr and temperatures at least $20^{\circ} \mathrm{C}$ warmer than present necessary for Nothofagus growth (Howard 1981; Sakai et al. 1981) are incompatible with Wright Valley evidence of long-term slope stability and cold, hyperarid conditions. Overall, our evidence indicates the presence in the Dry Valleys of a hyperarid cold desert environment devoid of Nothofagus since at least 3.7 Ma. Because such a polar environment is incompatible with the elevated temperatures needed to cause deglaciation of the East Antarctic Ice Sheet from surface meltdown, and because we find no evidence of the massive Late Pliocene ice-sheet advance necessary to strip 
marine diatoms from interior seas and emplace them in the Sirius deposits, we suggest that the East Antarctic Ice Sheet has remained relatively stable under a hyperarid, cold-desert environment since at least 3.7 Ma. We note here that our analysis applies only to whether the East Antarctic Ice Sheet collapsed due to surface meltdown; we do not address the possibility that the ice sheet could have shrunk due to the drawdown caused by ice streams (although we point out that there is no evidence that this ever occurred). One further implication is that the wet-temperate moorland environment reconstructed from fossils in the Sirius Group must have occurred before 3.7 Ma.

\section{Pliocene Behavior of the Antarctic Ice Sheet}

Having concluded that it is unlikely that the East Antarctic Ice Sheet underwent massive deglaciation due to surface meltdown, we now propose an alternate hypothesis for the Pliocene behavior of the ice sheet. Our own evidence from the Transantarctic Mountains presented here supports a stable and robust East Antarctic Ice Sheet with very modest fluctuations during the Pliocene. However, sequence stratigraphy from the Ross Sea indicates repeated Pliocene-age advances of marine-based ice across the continental shelf (Alonso et al. 1992). This apparent discrepancy between the Ross Sea and Transantarctic Mountains data prompted van der Wateren and Hindmarsh (1995) to question whether a stable East Antarctic Ice Sheet was compatible with the dynamic behavior exhibited by Ross Sea ice in Pliocene time. There is a Quaternary analog for the Pliocene Antarctic Ice Sheet, however, one which addresses both the stable behavior of the East Antarctic Ice Sheet (derived from our own glacial geologic data from the Transantarc- tic Mountains), and the dynamic behavior of the West Antarctic Ice Sheet (inferred from sequence stratigraphy from the Ross Sea).

In Quaternary time, the terrestrial Antarctic Ice Sheet has consisted of a stable interior core in East Antarctica and a dynamic, marine-based periphery in West Antarctica. The stable core in East Antarctica has undergone only modest fluctuations (Bockheim et al. 1989; Denton et al. 1989b). In contrast, the marine-based West Antarctic Ice Sheet has experienced widespread grounding-line oscillations in the Ross and Weddell Embayments (Denton et al. 1989a; Anderson et al. 1992). Polar climate conditions have persisted throughout the Quaternary, both in East and in West Antarctica. The difference in the magnitude of fluctuations is caused by the marine-based West Antarctic Ice Sheet being much more sensitive to sea-level changes than the terrestrial East Antarctic Ice Sheet.

Our evidence from Wright Valley suggests that, just as in the Quaternary, Pliocene ice in East Antarctica was stable and underwent only modest advances. Sequence stratigraphy from the Ross Sea, although not well-constrained chronologically, suggests that the periphery of the Pliocene Antarctic Ice Sheet was also dynamic (Alonso et al. 1992). Thus, the Pliocene ice sheet, similar to the Quaternary one, was composed of a stable terrestrial core and a dynamic marine-based fringe, both of which have existed under a polar desert climate.

\section{ACKNOWLEDGMENT}

This research was supported by the Office of Polar Programs of the National Science Foundation, by the National Oceanic and Atmospheric Administration, and by Sigma Xi. M. DuBois, T. Fenn, J. Florek, G. Hirsch, C. Lagerbom, and D. Marchant assisted in the field. R. Kelly drafted the figures.

\section{REFERENCES CITED}

Alonso, B.; Anderson, J. B.; Díaz, J. I.; and Bartek, L. R., 1992, Pliocene-Pleistocene seismic stratigraphy of the Ross Sea: Evidence for multiple ice sheet grounding episodes, in Elliot, D. H., ed., Contributions to Antarctic Research III: AGU Ant. Res. Ser. 57, p. 93-103.

Anderson, J. B.; Shipp, S. S.; Bartek, L.; and Reid, D. E., 1992, Evidence for a grounded ice sheet on the Ross Sea continental shelf during the late Pleistocene and preliminary paleodrainage reconstruction, in Elliot, D. H., ed., Contributions to Antarctic Research III: AGU Ant. Res. Ser. 57, p. 39-62.

Ashworth, A. C.; Harwood, D. M.; Webb, P. N.; and Mabin, M. G. C., 1996, A preliminary report on the terrestrial biota of the Meyer Desert Formation, Sirius
Group, Transantarctic Mountains: Geol. Soc. America Abs. with Prog., v. 28(7), p. A-224.

Askin, R. A., and Markgraf, V., 1986, Palynomorphs from the Sirius Formation, Dominion Range, Antarctica: Ant. Jour. U.S., v. 21, p. 34-35.

Barrett, P. J., 1991, Antarctica and global climatic change: A geological perspective, in Harris, C., and Stonehouse, B., eds., Antarctica and Global Climate Change: London, Belhaven Press, p. 35-52.

—; Adams, C. J.; McIntosh, W. C.; Swisher, C. C.; and Wilson, G. S., 1992, Geochronological evidence supporting Antarctic deglaciation three million years ago: Nature, v. 359, p. 816-818.

Bockheim, J. G., 1977, Soil development in the Taylor 
Valley and the McMurdo Sound region: Ant. Jour. U.S., v. 12, p. 105-108.

—; Wilson, S. C.; Denton, G. H.; Andersen, B. G.; and Stuiver, M., 1989, Late Quaternary ice-surface fluctuations of Hatherton Glacier, Transantarctic Mountains: Quat. Res., v. 31, p. 229-254.

Bull, C., and Carnein, C. R., 1968, The mass balance of a cold glacier: Meserve Glacier, Southern Victoria Land, Antarctica: ISAGE Symp. (Hanover, New Hampshire), p. 429-446.

Burckle, L. H., and Pokras, E. M., 1991, Implications of a Pliocene stand of Nothofagus (southern beech) within 500 kilometers of the South Pole: Antarctic Sci., v. 3, p. 389-403.

Chinn, T. J., 1980, Hydrological research report, Dry Valleys, Antarctica, 1970-1971: Ministry of Works and Development Report Ws 290, Christchurch, N.Z., $44 \mathrm{p}$.

Cronin, T. M., and Dowsett, H. J., 1993, Warm climates of the Pliocene: Geotimes, v. 38, p. 17-19.

Denton, G. H.; Bockheim, J. G.; Wilson, S. C.; and Stuiver, M., 1989a, Late Wisconsin and early Holocene glacial history, inner Ross Embayment, Antarctica: Quat. Res., v. 21, p. 151-182.

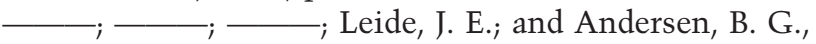
$1989 b$, Late Quaternary ice-surface fluctuations of Beardmore Glacier, Transantarctic Mountains: Quat. Res., v. 31, p. 183-209.

—; Sugden, D. E.; Marchant, D. R.; Hall, B. L.; and Wilch, T. I., 1993, East Antarctic Ice Sheet sensitivity to Pliocene climatic change from a Dry Valleys perspective: Geogr. Ann., v. 75A, p. 155-204.

Hall, B. L.; Denton, G. H.; Lux, D. L.; and Bockheim, J. G., 1993, Late Tertiary Antarctic paleoclimate and icesheet dynamics inferred from surficial deposits in Wright Valley: Geogr. Ann., v. 75A, p. 239-267.

Hall, S. A., 1975, Palynological investigations of Quaternary sediment from Lake Vanda, Antarctica: Ant. Jour. U.S., v. 10, p. 173-174.

Harwood, D. M., 1986, Recycled siliceous microfossils from the Sirius Formation: Ant. Jour. U.S., v. 21, p. $101-103$.

Howard, T. M., 1981, Southern closed forests, in Groves, R. H., ed., Australian Vegetation: New York, Cambridge University Press, p. 102-120.

Huybrechts, P., 1993, Glaciological modeling of the late Cenozoic East Antarctic Ice Sheet: Stability or dynamism?: Geogr. Ann., v. 75A, p. 221-238.

Kennett, J. P., and Hodell, D. A., 1993, Evidence for relative climatic stability of Antarctica during the early Pliocene: A marine perspective: Geogr. Ann., v. 75A, p. 205-220.

Marchant, D. R.; Denton, G. H.; and Swisher, C. C., 1993, Miocene-Pliocene-Pleistocene glacial history of Arena Valley, Quartermain Mountains, Antarctica: Geogr. Ann., v. 75A, p. 269-302.

Mercer, J. H., 1986, Southernmost Chile: A modern ana$\log$ of the southern shores of the Ross Embayment during Pliocene warm intervals: Ant. Jour. U.S., v. 21, p. 103-105.
Pisano, E., 1977, Fitogeografia de Fuego-Patagonia Chilena I. Comunida des vegetales entre las latitudes 52 y $56^{\circ}$ S: Anales Insti. Patagonia, v. 8, p. 121-248.

- 1983, The Magellanic tundra complex, in Gore, A. J. P., ed., Mire: Swamp, Bog, Fen, and Moor (Ecosystems of the World Regional Studies 4B): New York, Elsevier, p. 295-329.

Prentice, M. L.; Bockheim, J. G.; Wilson, S. C.; Burckle, L. H.; Hodell, D. A.; Schlüchter, C.; and Kellogg, D. E., 1993, Late Neogene Antarctic glacial history: Evidence from central Wright Valley, in Kennett, J. P., and Warnke, D. A., eds., The Antarctic paleoenvironment: A perspective on global change: AGU Ant. Res. Ser., v. 60, p. 207-250.

Puigdefabregas, J.; del Barrio, G.; and Iturraspe, R., 1988, Régimen térmico estacional de un ambiente montañoso en la Tierra del Fuego, con especial atención al límite superior del bosque: Pirineos, v. 132, p. 37-48.

Robin, G. de Q., 1988, The Antarctic Ice Sheet, its history, and response to sea level and climatic changes of the past 100 million years: Palaeogeog. Palaeoecol. Palaeoclimat., v. 67, p. 31-50.

Robinson, P. H., 1984, Ice dynamics and thermal regime of Taylor Glacier, South Victoria Land, Antarctica: Jour. Glac., v. 30, p. 153-160.

Sakai, A.; Paton, D. M.; and Wardle, P., 1981, Freezing resistance of trees of the south temperate zone, especially subalpine species of Australasia: Ecology, v. 62, p. 563-570.

Thompson, D. C.; Craig, R. F.; and Bromley, A. M., 1971, Climate and surface heat balance in an Antarctic dry valley: N.Z. Jour. Sci., v. 14, p. 245-251.

Turner, R. D., 1967, A new species of Chlamys from Wright Valley, McMurdo Sound, Antarctica: N.Z. Jour. Geol. Geophys., v. 10, p. 446-455.

van der Wateren, R., and Hindmarsh, R., 1995, Stabilists strike again: Nature, v. 376, p. 389-391.

Webb, P. N., 1972, Wright Fjord, a marine invasion of an Antarctic dry valley: Ant. Jour. U.S., v. 7, p. 227-234.

, 1974, Micropaleontology, paleoecology, and correlation of the Pecten gravels, Wright Valley, Antarctica: Jour. Foram. Res., v. 4, p. 185-189.

— history of the Ross Embayment, Antarctica: Quat. Sci. Rev., v. 10, p. 215-224.

- , and 1 1993, Pliocene fossil Nothofagus (southern beech) from Antarctica: Phytogeography, dispersal strategies, and survival in high latitude glacial-deglacial environments, in Alden, J., et al., eds., Forest Development in Cold Climates: New York, Plenum, p. 135-165.

— - $\longrightarrow$ McKelvey, B. C.; Mercer, J. H.; and Scott, L. D., 1984, Cenozoic marine sedimentation and ice volume variation on the East Antarctic craton: Geology, v. 12, p. 287-291.

Wilch, T. I.; Denton, G. H.; Lux, D. R.; and McIntosh, W. C., 1993, Limited Pliocene glacier extent and surface uplift in Middle Taylor Valley, Antarctica: Geogr. Ann., v. 75A, p. 331-351. 